\title{
Characterization of Extracellular Proteases of Aeromonas hydrophila
}

\author{
A. C. Pansare, N. F. Lewis and V. Venugopal* \\ Food Technology and Enzyme Engineering Division, \\ Bbabha Atomic Research Centre, \\ Bombay 400 085, India \\ Received December 10, 1985
}

\begin{abstract}
Two endoproteases, proteinase-I and proteinase-II, and one aminopeptidase were isolated from the culture supernatant of Aeromonas hydrophila by ammonium sulfate precipitation, gradient elution on diethylaminoethyl-Sephadex A-50 and Sephadex G-75 column chromatography. The molecular weights of the proteinases and aminopeptidase ranged between 30,000 to 48,000 . The proteinases had comparable $\mathrm{pH}(8.5)$ and temperature $\left(48 \sim 50^{\circ} \mathrm{C}\right)$ optima. The aminopeptidase assayed using L-leucine- $p$-nitroanilide showed maximum activity at $\mathrm{pH} 8.0$ and at a temperature of $70^{\circ} \mathrm{C}$. The aminopeptidase was remarkably heat stable, while the proteinases were heat sensitive. Both the proteinases hydrolysed several proteins including fish myofibrillar proteins. Divalent cations like $\mathrm{Fe}^{2+}, \mathrm{Cu}^{2+}$ and $\mathrm{Zn}^{2+}$ inhibited the activities of the two proteinases while $\mathrm{Ca}^{2+}$ and $\mathrm{Mg}^{2+}$ did not affect either the activities of the proteinases or that of the aminopeptidase. The aminopeptidase was inhibited by metal chelating agents as well as thiol reagents.
\end{abstract}

Aeromonas hydrophila, commonly found in stagnant water, forms part of the normal microflora of fish and other aquatic animals. ${ }^{1,2)}$ The bacterium has been recognized as an enteric pathogen ${ }^{3,4)}$ as well as an active spoiler of fish under refrigeration. ${ }^{5,6)}$ The pathogenicity and spoilage potential of $A$. hydrophila can be attributed to its ability to secrete several extracellular virulence factors including hemolysins, lipases and proteases. ${ }^{7}$ Extracellular proteases from psychrotropic bacteria are also known to cause deterioration of flesh foods during refrigerated storage. ${ }^{8)}$ Attention has, therefore, been focused on regulation of the synthesis and the properties of extracellular proteases of spoilage microorganisms. O'Reilly and Day ${ }^{9)}$ showed that the synthesis of an extracellular protease by $A$. hydrophila was dependent on the $\mathrm{pH}$, aeration and temperature of the growth medium. We recently observed that the extracellular protease synthesis by this bacterium did not require complex nitrogen compounds, but was supported by several individual amino acids, while the enzyme was repressed by ammonium and glutamine. ${ }^{10}$ We also found that the secretion of the enzyme was inhibited by certain food preservatives ${ }^{11)}$ as well as by iron. ${ }^{12}$ The present report pertains to the isolation and characterization of two extracellular pro= teinases and one aminopeptidase produced by A. hydrophila.

\section{MATERIALS AND METHODS}

Organism and growth conditions. Aeromonas hydrophila was isolated from Indian mackerel (Rastrelliger kanagurta). The bacterium was grown in $0.8 \%$ Nutrient Broth (Difco) and the active culture $(18 \mathrm{hr})$ was inoculated at $1 \%$ level into one liter flasks, each containing $500 \mathrm{ml}$ of $0.8 \%$ Nutrient broth. The flasks were incubated at $28^{\circ} \mathrm{C}$ on a rotary shaker for $24 \mathrm{hr}$ after which the cultures were centrifuged at $5920 \times g$ for $10 \mathrm{~min}$. The pooled culture supernatant $(2500 \mathrm{ml})$ was used as the source of crude enzymes. The purification procedures were carried out at $0 \sim 2^{\circ} \mathrm{C}$.

Lyophilization. The culture supernatant was lyophilized and the powder was dissolved in about $300 \mathrm{ml}$ of $50 \mathrm{~mm}$ phosphate buffer, $\mathrm{pH}$ 7.5. Powdered ammonium sulfate

* To whom correspondence should be addressed. 
was added with constant stirring to the crude enzyme preparation to $80 \%$ saturation. The mixture was allowed to stand overnight at $4{ }^{\circ} \mathrm{C}$ and centrifuged at $5,920 \times g$ for $10 \mathrm{~min}$, and then the precipitate was collected. The precipitate was dissolved in $50 \mathrm{~mm}$ potassium phosphate buffer, $\mathrm{pH} 7.5(50 \mathrm{ml})$, and then dialysed at $2^{\circ} \mathrm{C}$ for $24 \mathrm{hr}$ against three changes of the buffer. The dialysed enzyme solution was centrifuged at $5,920 \times g$ for $10 \mathrm{~min}$ and the supernatant obtained was used for further purification.

DEAE-Sephadex A-50 column chromatography. The crude enzyme $(10 \mathrm{ml})$ was applied to a DEAE-Sephadex A-50 column $(21.5 \times 1.8 \mathrm{~cm})$ that had been equilibrated with $50 \mathrm{~mm}$ phosphate buffer, $\mathrm{pH}$ 7.5. The unbound proteins were eluted with the starting buffer after which a linear $\mathrm{NaCl}$ gradient ( 0 to $0.5 \mathrm{M}$ ) was applied, with elution at a rate of $12 \mathrm{ml}$ per hour. Fractions $(3 \mathrm{ml})$ were collected and examined for proteinase and aminopeptidase activities. The active fractions were pooled and dialysed against $50 \mathrm{~mm}$ phosphate buffer, $\mathrm{pH} 7.5$, for $24 \mathrm{hr}$ with two changes of the buffer, and then the dialysed enzyme was lyophilized.

Sephadex G-75 chromatography. The lyophilized enzyme was dissolved in $5 \mathrm{ml}$ of $50 \mathrm{~mm}$ phosphate buffer, $\mathrm{pH}$ 7.5 , and then applied to a Sephadex G-75 column $(63 \times$ $1.6 \mathrm{~cm}$ ) equilibrated with the same buffer. Elution was carried out a flow rate of $15 \mathrm{ml}$ per hour and fractions of $2.5 \mathrm{ml}$ each were collected. The fractions containing the enzyme were pooled, concentrated by lyophilization and then taken up in $50 \mathrm{~mm}$ phosphate buffer, $\mathrm{pH} 7.5$.

Proteinase assay. The assay system, containing $15 \mathrm{mg}$ hemoglobin (Difco), $1.5 \mathrm{ml}$ of $100 \mathrm{~mm}$ phosphate buffer, $\mathrm{pH} 7.5$, and enzyme in a total volume of $2.0 \mathrm{ml}$, was incubated at $50^{\circ} \mathrm{C}$ for $30 \mathrm{~min}$. The reaction was stopped by the addition of $1 \mathrm{ml}$ of $20 \%$ trichloroacetic acid (TCA). After $15 \mathrm{~min}$, the supernatant was collected by filtration through Whatman No. 1 filter paper and tyrosine in the supernatant was determined as described earlier. ${ }^{8)}$ One unit of enzyme activity was expressed as $\mu$ mol tyrosine liberated per mg protein in $30 \mathrm{~min}$.

Aminopeptidase assay. Aminopeptidase activity was determined using leucine $p$-nitroanilide as the substrate. ${ }^{13)} \mathrm{L}$ Leucine $p$-nitroanilide $(29 \mathrm{mg})$ was dissolved in $8 \mathrm{ml}$ of distilled water and $2 \mathrm{ml}$ of dimethylsulfoxide. The stock solution was diluted 1:10 with distilled water before the assay. The assay system, containing $0.3 \mathrm{ml}$ of this solution,

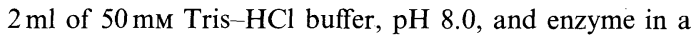
total volume of $3.0 \mathrm{ml}$, was incubated at $70^{\circ} \mathrm{C}$ for $10 \mathrm{~min}$. The reaction was stopped with $1 \mathrm{ml}$ of $1 \%$ mercuric chloride and then the color was measured at $405 \mu \mathrm{m}$. One unit of aminopeptidase activity was defined as $1 \mu \mathrm{mol}$ of $p$ nitroaniline formed per $\mathrm{mg}$ of enzyme during the incubation.
Molecular weight determination. The molecular weights of the proteases were determined from the elution profiles of the enzymes on a $63 \times 1.6 \mathrm{~cm}$ Sephadex G-100 column. The column was calibrated using proteins of known mol. wt., namely lysozyme $(12,000)$, pepsin $(35,000)$ and bovine serum albumin $(69,000)$. The void volume was determined with blue detran.

Effect of $\mathrm{pH}$ on enzyme activity. The assay system for proteinase contained $15 \mathrm{mg}$ hemoglobin in $1.5 \mathrm{ml}$ each of the following buffers at $100 \mathrm{~mm}$ concentration: citratephosphate buffer ( $\mathrm{pH} 3.0$ to 5.0), potassium phosphate buffer ( $\mathrm{pH} 6$ to 8.0), boric acid-borax buffer ( $\mathrm{pH} \mathrm{8.5)} \mathrm{and}$ glycine- $\mathrm{NaOH}$ buffer ( $\mathrm{pH} 9.0$ to 10.0 ). For aminopeptidase activity, $100 \mathrm{~mm}$ Tris- $\mathrm{HCl}$ was used at $\mathrm{pH}$ values ranging from 7.0 to 9.0 .

Effect of temperature on enzyme activity. The assay system, containing hemoglobin or L-leucine- $p$-nitroanilide, was preincubated for $30 \mathrm{~min}$ at temperatures in the range of 0 to $80^{\circ} \mathrm{C}$ before the enzyme was added. The enzyme activity was determined as described above.

Heat and radiation stability. The enzyme solution containing $60 \sim 90 \mu \mathrm{g} / \mathrm{ml}$ protein in $50 \mathrm{~mm}$ phosphate buffer, $\mathrm{pH} 7.5$, was subjected to heat treatment at $65^{\circ} \mathrm{C}$ or $70^{\circ} \mathrm{C}$ for periods ranging from 0 to $90 \mathrm{~min}$, or subjected to radiation treatment at doses ranging from 0 to $400 \mathrm{krad}$ in a ${ }^{60} \mathrm{Co}$ Gamma Cell (BARC model; dose rate, $115 \mathrm{krad}$ per hour). After the heat or radiation treatment, the residual enzyme activity was determined as described above.

Inhibitor studies. The enzyme solution, containing $60 \sim$ $90 \mu \mathrm{g}$ protein per ml protein, was dialysed against $50 \mathrm{~mm}$ Tris- $\mathrm{HCl}$ buffer, $\mathrm{pH} 7.5$, for $4 \mathrm{hr}$. The dialysed enzyme was incubated for $15 \mathrm{~min}$ at room temperature with the following compounds at $1 \mathrm{~mm}$ concentration: ethylenediamine tetraacetic acid (EDTA), dipyridyl, $o$-phenanthroline, iodoacetamide, cysteine, dithioerythreitol, $p$-chloromercuribenzoate and phenylmethyl sulfonylfluoride. After treatment with the inhibitors, the proteinase activity was determined with bovine serum albumin in $25 \mathrm{~mm}$ Tris- $\mathrm{HCl}$ buffer, $\mathrm{pH} 7.5$, and the aminopeptidase activity was determined with L-leucine- $p$-nitroanilide, as described earlier.

Effects of divalent metal ions. Solutions of divalent metal salts. viz., $\mathrm{CuCl}_{2} \cdot 2 \mathrm{H}_{2} \mathrm{O}, \mathrm{FeSO}_{4} \cdot 7 \mathrm{H}_{2} \mathrm{O}, \mathrm{CaCl}_{2} \cdot 2 \mathrm{H}_{2} \mathrm{O}$, $\mathrm{ZnCl}_{2}, \mathrm{MgCl}_{2} \cdot 6 \mathrm{H}_{2} \mathrm{O}$ and $\mathrm{MnCl}_{2} \cdot 4 \mathrm{H}_{2} \mathrm{O}$ at $1 \mathrm{~mm}$ concentration, were each preincubated with the enzyme protein $(100 \mu \mathrm{g})$ for $15 \mathrm{~min}$ at room temperature prior to determining the enzyme activity.

Substrate specificity. The proteinase activity was determined using various proteins as substrates, namely, hemoglobin, lysozyme, ribonuclease, myoglobin and fish myofibrillar proteins. The fish myofibrillar proteins were 
prepared as described by Venugopal et al. ${ }^{8)}$

Protein concentration was determined by the method of Lowry et al. ${ }^{14)}$ using bovine serum albumin as the standard.

\section{RESULTS}

The results of typical purification of the proteinases are summarised in Table I. Cell free supernatant (2.5 liters) was used as the starting material. Preliminary experiments showed that the protein content of the dialysed cell free supernatant, as determined by Lowry's method, ${ }^{14)}$ was about $980 \mu \mathrm{g}$ per ml. The culture supernatant was concentrated by lyophilization prior to ammonium sulfate precipitation. The ammonium sulfate precipitate obtained was dissolved in a minimum volume

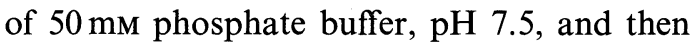
dialysed against the above buffer. The dialysed enzyme was then absorbed on a DEAESephadex A-50 column under the chromatographic conditions employed. Two enzymes showing proteinase activities were found to be eluted with the $\mathrm{NaCl}$ gradient. Proteinase-I was eluted at approximately $0.13 \mathrm{M} \mathrm{NaCl}$ and Proteinase-II at $0.27 \mathrm{M} \mathrm{NaCl}$. The aminopeptidase was eluted at $0.3 \mathrm{M} \mathrm{NaCl}$ (Fig. 1). The proteinases and aminopeptidase were sepa-

TABle I. Purification of Aeromonas hydrophila Proteinases

\begin{tabular}{lccccc}
\hline Purification step & $\begin{array}{c}\text { Total } \\
\text { volume } \\
(\mathrm{ml})\end{array}$ & $\begin{array}{c}\text { Total } \\
\text { activity } \\
\text { (units) }\end{array}$ & $\begin{array}{c}\text { Total } \\
\text { protein } \\
\text { (mg) }\end{array}$ & $\begin{array}{c}\text { Specific } \\
\text { activity } \\
\text { (units/mg) }\end{array}$ & $\begin{array}{c}\text { Fold } \\
\text { purification }\end{array}$ \\
\hline $\begin{array}{l}\text { Culture filtrate } \\
\begin{array}{c}\text { 80\% Ammonium sulphate } \\
\text { fraction }\end{array}\end{array}$ & 2500 & 3750 & 2450 & 1.5 & 1 \\
$\begin{array}{c}\text { DEAE-Sephadex A-50 } \\
\text { chromatography }\end{array}$ & 18 & 900 & 293 & 3 & 2 \\
$\quad$ Proteinase-I & & & & \\
$\quad$ Proteinase-II & 6 & 162 & 6 & 27.5 & 18 \\
$\begin{array}{c}\text { Sephadex G-75 } \\
\text { chromatography } \\
\text { Proteinase-I }\end{array}$ & 8 & 232 & 12 & 19 & 12 \\
$\quad$ Proteinase-II & 26.5 & 156 & & & 67 \\
\hline
\end{tabular}

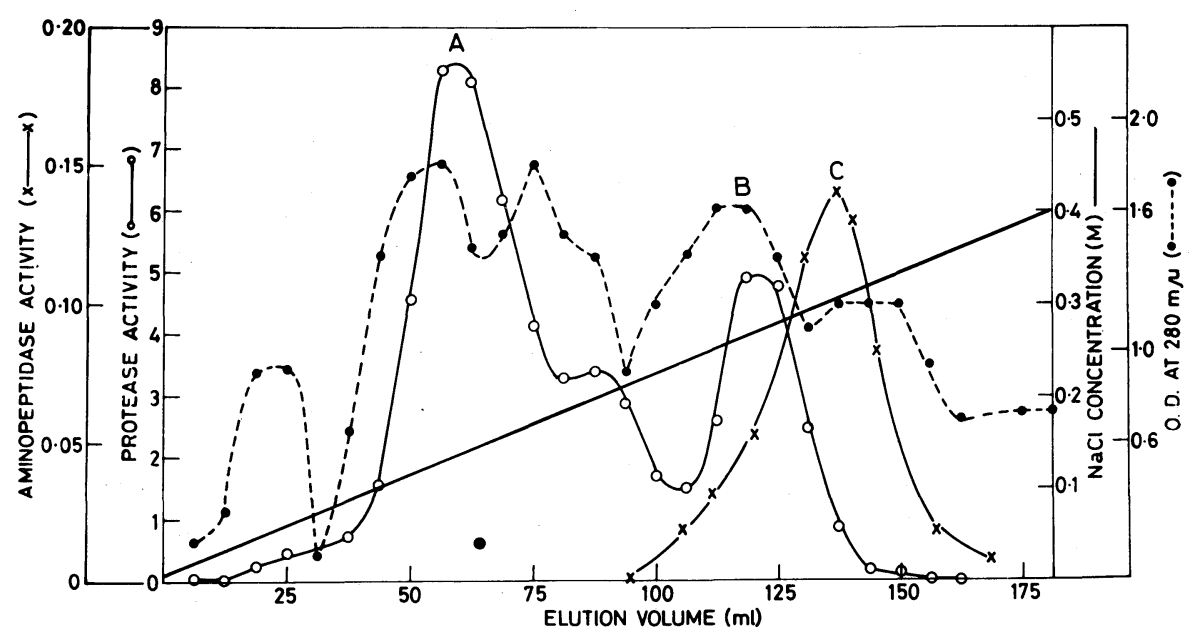

FIG. 1. Elution Profiles of $A$. hydrophila Proteases on a DEAE-Sephadex A-50 Column.

A, proteinase-I; B, proteasease-II; C, aminopeptidase. The details are given in the text. 
Table II. Purification of Aeromonas hydrophila.AminopePtidase

\begin{tabular}{cccccc}
\hline Purification step & $\begin{array}{c}\text { Total } \\
\text { volume } \\
(\mathrm{ml})\end{array}$ & $\begin{array}{c}\text { Total } \\
\text { protein } \\
(\mathrm{mg})\end{array}$ & $\begin{array}{c}\text { Total } \\
\text { activity } \\
\text { (units) }\end{array}$ & $\begin{array}{c}\text { Specific } \\
\text { activity } \\
\text { (units/mg) }\end{array}$ & $\begin{array}{c}\text { Fold } \\
\text { purification }\end{array}$ \\
\hline $\begin{array}{c}\text { Culture filtrate } \\
80 \% \text { Ammonium sulphate } \\
\text { fraction }\end{array}$ & 2500 & 4400 & 690 & 0.4 & 1 \\
$\begin{array}{c}\text { DEAE-Sephadex A-50 } \\
\text { chromatography }\end{array}$ & 12 & 402 & 32.4 & 0.52 & 12 \\
$\begin{array}{c}\text { Sephadex G-100 } \\
\text { chromatography }\end{array}$ & 12 & 14.5 & 174 & 62 & 30 \\
\hline
\end{tabular}

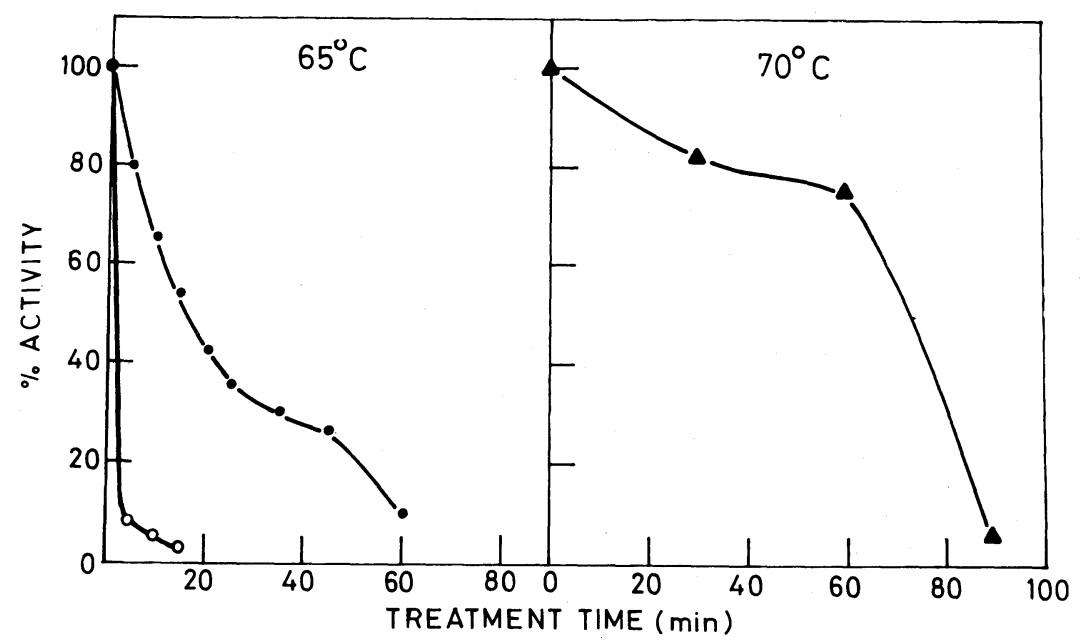

FIG. 2. Thermal Inactivation Profiles of $A$. hydrophila Proteases.

, proteinase-I; $O$, proteinase-II;

$\boldsymbol{\Delta}$, aminopeptidase.

rately purified starting from separate culture filtrates. The proteinase rich fractions from DEAE-Sephadex A-50 chromatography were pooled, dialysed against the above phosphate buffer and then lyophilized. The enzyme preparations in 5 to $6 \mathrm{ml}$ of $50 \mathrm{~mm}$ phosphate buffer, $\mathrm{pH} 7.5$, were charged separately on a column of Sephadex G-75. Both proteinases were eluted as single symmetrical peaks, but showed different elution profiles. Proteinase-I was eluted at an elution volume of $62 \mathrm{ml}$ while proteinase-II was eluted at $45 \mathrm{ml}$ on a Sephadex G-75 column. The aminopeptidase was eluted at $70 \mathrm{ml}$ on Sephadex G-100. The extents of purification obtained were $60 \sim 67$ fold for the proteinases (Table I) and 155 fold for the aminopeptidase (Table II). The low level of protein in the culture supernatant could partially account for the comparatively low levels of purification of the enzymes.

The molecular weights of the enzymes, as determined by gel filtration, were about 40,000 for proteinase-I, 48,000 for proteinase-II and 30,500 for the aminopeptidase.

Both the proteinases were found to have a $\mathrm{pH}$ optimum of 8.5. Enzymes I and II showed more than $50 \%$ of their maximum activities in the $\mathrm{pH}$ ranges of 6 to 10 and 7.5 to 10 , respectively. The aminopeptidase showed $70 \%$ activity in the $\mathrm{pH}$ range of 7.5 to 8.5 , the maximum being at $\mathrm{pH} 8.0$.

The optimum temperature of proteinase-I was found to be $50^{\circ} \mathrm{C}$ and that of proteinase-II to be $48^{\circ} \mathrm{C}$. Proteinase-I showed approximate- 
ly $66 \%$ of the maximum activity at $65^{\circ} \mathrm{C}$ and about $50 \%$ activity at $37^{\circ} \mathrm{C}$, while proteinaseII retained $50 \%$ of its activity at $23^{\circ} \mathrm{C}$ and about $26 \%$ at $65^{\circ} \mathrm{C}$. The aminopeptidase, on the other hand, showed maximum activity at $70^{\circ} \mathrm{C}$.

Figure 2 shows the thermal inactivation profiles for the proteinases. After heat treatment at $65^{\circ} \mathrm{C}$ for half an hour, more than $30 \%$ of the proteinase-II activity remained. At the end of $1 \mathrm{hr}$ at $65^{\circ} \mathrm{C}$ only $8.5 \%$ of the enzyme activity remained. Proteinase-II was comparatively more temperature labile, $90 \%$ of the activity being lost after $5 \mathrm{~min}$ treatment at $65^{\circ} \mathrm{C}$. In contrast, the aminopeptidase was remarkably heat stable. Thus, as shown in Fig. 2 , after heat treatment at $70^{\circ} \mathrm{C}$ for $1 \mathrm{hr}$ only $25 \%$ of the activity was lost.

The effect of gamma radiation on the enzymes is shown in Fig. 3. While $50 \%$ activity of proteinase-I remained after exposure to a radiation dose of about $125 \mathrm{krad}$, only about $13 \%$ of the maximum activity remained after subjecting the enzyme to a dose of $370 \mathrm{krad}$. Proteinase-II was found to be more sensitive to gamma radiation; a dose of $25 \mathrm{krad}$ resulted in a $50 \%$ loss in maximum activity while exposure to $75 \mathrm{krad}$ destroyed about $95 \%$ of its activity. The aminopeptidase was also similarly sensitive to radiation, losing about $65 \%$ of its activity upon exposure to a dose of $115 \mathrm{krad}$ (Fig. 3).

Table III shows the specific activities of proteinases-I and II with respect to different substrates. Both the enzymes had broad substrate specificities. Proteinase-I was most active against fish myofibrillar proteins, followed by myoglobin and ribonuclease. Proteinase-II was found to be most active against ribonuclease followed by myofibrillar proteins. Lysozyme and myoglobin showed about $56 \%$ and $62 \%$ of the proteinase-II activity with respect to ribonuclease, while bovine serum albumin was least susceptible to proteinase-II.

Table IV presents the activities of proteinases-I and -II in the presence of different metals. The activities of both proteinase-I and proteinase-II were inhibited by $\mathrm{Fe}^{2+}, \mathrm{Cu}^{2+}$

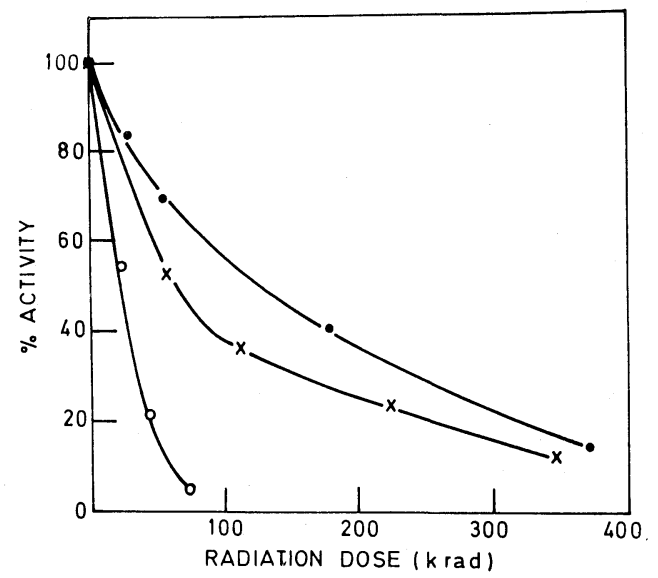

FIG. 3. Radiation Inactivation Profiles of $A$. hydrophila Proteases.

$\boldsymbol{O}$, proteinase-I; $\mathbf{O}$, proteinase-II; $\times$, aminopeptidase.

Table III. Activities of Proteinases I AND II against Various Proteins

\begin{tabular}{lcc}
\hline \multicolumn{1}{c}{ Substrate } & Proteinase-I & Proteinase-II \\
\hline Hemoglobin & 250 & 96 \\
Myoglobin & 267 & 70 \\
Myofibrillar protein & 328 & 104 \\
$\quad$ fraction from fish & & 113 \\
Ribonuclease & 260 & 64 \\
Lysozyme & 155 & 42 \\
Bovine serum albumin & 177 & \\
\hline
\end{tabular}

The values are expressed as $\mu \mathrm{mol}$ tyrosine liberated by $\mathrm{mg}$ enzyme in $30 \mathrm{~min}$.

and $\mathrm{Zn}^{2+}$, while both enzymes were unaffected by $\mathrm{Ca}^{2+}$ or $\mathrm{Mg}^{2+}$. Aminopeptidase activity was lost in presence of $\mathrm{Mn}^{2+}$ but not in that of $\mathrm{Zn}^{2+}$.

Table IV also presents the effects of various inhibitors on the enzymes. Chelating compounds like EDTA and $o$-phenanthroline exhibited high inhibitory activity toward proteinase-I. Parachloromercuribenzoate did not show any significant inhibition of either proteinase. The serine protease inhibitor, phenylmethyl sulfonylfluoride (PMSF), was comparatively more inhibitory against proteinaseII. The aminopeptidase activity was significantly lost in the presence of EDTA and 1,10phenanthroline, and also in the presence of thiol reagents like cysteine and dithioeryth- 
Table IV. Effect of Various Compounds on the Activity of $A$. hydrophila Proteases

\begin{tabular}{|c|c|c|c|c|}
\hline \multirow{2}{*}{ Compounds tested } & \multirow{2}{*}{$\begin{array}{c}\text { Final } \\
\text { Concentration } \\
(\mathrm{mm})\end{array}$} & \multicolumn{3}{|c|}{$\%$ Relative activity } \\
\hline & & Proteinase-I & Proteinase-II & Aminopeptidase \\
\hline None & 0 & 100 & 100 & 100 \\
\hline $\mathrm{FeSO}_{4}$ & 1 & 23 & 0 & 90 \\
\hline $\mathrm{MnCl}_{2}$ & 1 & 55 & 113 & 33 \\
\hline $\mathrm{CuCl}_{2}$ & 1 & 17 & 30 & - \\
\hline $\mathrm{CaCl}_{2}$ & 1 & 100 & 150 & 88 \\
\hline $\mathrm{MgCl}_{2}$ & 1 & 96 & 117 & 107 \\
\hline $\mathrm{ZnCl}_{2}$ & 1 & 16 & 10 & 105 \\
\hline Ethylenediamine tetracetic acid & 1 & 40 & 44 & 53 \\
\hline 1,10-Phenanthroline & 1 & 44 & 69 & 0 \\
\hline$\alpha, \alpha^{\prime}$-Dipyridyl & 1 & - & - & 65 \\
\hline$p$-Chloromercuribenzoate & 1 & 73 & 100 & 65 \\
\hline Iodoacetamide & 1 & 32 & 94 & 100 \\
\hline Phenylmethylsulfonylfluoride & 1 & 59 & 34 & 57 \\
\hline Cysteine & 1 & - & - & 80 \\
\hline Cysteine & 5 & - & - & 35 \\
\hline Dithioerythreitol & 1 & - & - & 15 \\
\hline Dithioerythreitol & 5 & - & - & 10 \\
\hline
\end{tabular}

-, not tested.

reitol.

\section{DISCUSSION}

A. hydrophila produces at least three extracellular proteases including two types of proteinases and one aminopeptidase, which were isolated and characterised. Proteinase-I, which was eluted at a salt concentration of $0.13 \mathrm{M}$ from a DEAE-Sephadex A-50 column, had a molecular weight of about 40,000 , while proteinase-II, eluted at a salt concentration of $0.27 \mathrm{M}$, had a mol. wt. of about 48,000 . The aminopeptidase was co-eluted with proteinaseII at a salt concentration of about $0.3 \mathrm{M}$. The enzyme had a mol. wt. 30,500 and was optimally active at $\mathrm{pH} 8.0$ and at a temperature of $70^{\circ} \mathrm{C}$. Both the proteinases had a $\mathrm{pH}$ optimum of about 8.5 and were appreciably active over the $\mathrm{pH}$ range of 6 to 10 . The enzymes were sensitive to metal chelating agents. Several proteases produced by Gram-negative bacteria have been shown to possess alkaline $\mathrm{pH}$ optima and to be sensitive to metal chelating compounds. ${ }^{15)}$ In these respects, the proteinases of $A$. hydrophila resemble alkaline pro- teases which are sensitive to metal chelating compounds. According to Morihara, ${ }^{15)}$ such proteases also possess broad substrate specificities. Thus, the present proteinases were also found to act on several proteins.

Proteinase-II differed from proteinase-I in certain respects. It had a higher molecular weight and exhibited higher sensitivities towards heat and radiation treatment. Proteinase-II showed a lower electrophoretic mobility than proteinase I (data not shown in results). Proteinase-II was comparatively more sensitive towards inhibition by the serine-protease inhibitor, phenylmethyl sulfonylfluoride, suggesting it to be a serine-protease. Both the enzymes were inhibited by metals like $\mathrm{Fe}^{2+}$, $\mathrm{Cu}^{2+}$ and $\mathrm{Zn}^{2+}$, but not by $\mathrm{Ca}^{2+}$ or $\mathrm{Mg}^{2+}$, even at $10 \mathrm{~mm}$ level. Dahle ${ }^{16)}$ has reported the purification and properties of two proteases from Aeromonas liquefaciens. He observed that both the enzymes appreciably differed from one another with respect to their $\mathrm{pH}$ optima, thermoresistance and sensitivities towards certain inhibitors. The properties of the two proteinases from $A$. hydrophila are comparable with those of the extracellular proteases of 
other organisms belonging to the same genus. Thus the extracellular protease produced by Aeromonas salmonicida ${ }^{17)}$ could be similar to proteinase-I of $A$. hydrophila. The $A$. salmonicida proteinase has a $\mathrm{pH}$ optimum of 9.0 and a temperature optimum of $48^{\circ} \mathrm{C}$, and is insensitive to inhibition by parachloromercuribenzoate. ${ }^{17)}$ The optimum $\mathrm{pH}$ values of the two proteinases of $A$. hydrophila were also within the $\mathrm{pH}$ range, $8 \sim 11$, reported for another Aeromonas protease by Shieh and Maclean. ${ }^{18)}$ The enzyme from $A$. salmonicida has a mol. wt. of 11,000 , which is much smaller than those found for the $A$. hydrophila proteinases. In contrast, the $A$. proteolytica extracellular protease has neutral $\mathrm{pH}$ optimum and a molecular weight of $34,800 .^{19)}$

A. hydrophila also produced an extracellular aminopeptidase, which was remarkably thermostable. Heat treatment at $70^{\circ} \mathrm{C}$ for $1 \mathrm{hr}$ caused loss of only about $25 \%$ of its original activity. Furthermore, the enzyme also required a temperature as high as $70^{\circ} \mathrm{C}$ for maximum activity. The radiation sensitivity of the aminopeptidase was, however, comparable to those of the proteinases. The enzyme was inhibited by metal chelators and thiol reagents, suggesting it to be a metalloenzyme. Prescott et al. ${ }^{20)}$ reported that the Aeromonas proteolytica extracellular aminopeptidase was a zinc-containing enzyme. The $A$. proteolytica aminopeptidase was also optimally active at $70^{\circ} \mathrm{C}$ and had a mol. wt. of 29,500 .

Several bacteria have been recognized to release aminopeptidases during growth and the pathogenicity of many of these organisms has been attributed to their aminopeptidase activity. ${ }^{21)}$ The pathogenicity and spoilage potential of $A$. hydrophila could be correlated to the ability of the bacterium to secrete endoproteases as well as an aminopeptidase during growth.

\section{REFERENCES}

1) T. C. Hazen, C. B. Flermans, R. P. Hirsch and G. W. Esch, Appl. Env. Microbiol., 36, 731 (1978).

2) J. B. Kaper, H. Lockman and R. R. Colewell, J. Appl. Bacteriol., 50, 359 (1981).

3) B. Austin and D. A. Austin, J. Appl. Bacteriol., 58, 483 (1985).

4) E. Annapurna and S. C. Sanyal, J. Med. Microbiol., 10, 317 (1977).

5) P. Lerke, L. Farber and R. Adams, Appl. Microbiol., 13, 625 (1965)

6) N. F. Lewis, M. D. Alur and U. S. Kumta, Ind. J. Exp. Biol., 9, 45 (1971).

7) A. Ljung and T. J. Wadstrom, Toxicol. Toxins Rev., 1, 257 (1982-83).

8) V. Venugopal, M. D. Alur and N. F. Lewis, J. Food Sci., 48, 671 (1983).

9) T. O'Reilly and D. F. Day, Appl. Env. Microbiol., 45, 1132 (1983).

10) A. C. Pansare, V. Venugopal and N. F. Lewis, J. Appl. Bacteriol., 58, 101 (1985).

11) V. Venugopal, A. C. Pansare and N. F. Lewis, J. Food Sci., 49, 1078 (1984).

12) A. C. Pansare, V. Venugopal and N. F. Lewis, Agric. Biol. Chem., 49, 2451 (1985).

13) H. Ansari and L. Stevens, J. Gen. Microbiol., 129, 1637 (1983).

14) O. H. Lowry, N. J. Rosebrough, A. L. Farr and R. J. Randall, J. Biol. Chem., 193, 265 (1951).

15) K. Morihara, Adv. Enzymol., 41, 179 (1974).

16) H. K. Dahle, Acta Path. Microbiol. Scand. Sec. B., 79, 726 (1971).

17) S. Mellegaard, J. Appl. Bacteriol., 54, 289 (1983).

18) H. S. Shieh and J. R. Maclean, Int. J. Biochem., 6, 563 (1975).

19) S. H. Wilkes and J. M. Prescott, Methods in Enzymol., 45, 404 (1976).

20) J. M. Prescott, S. H. Wilkes, F. W. Wagner and K. J. Wilson, J. Biol. Chem., 246, 1756 (1971).

21) R. R. Watson, Methods in Enzymol., 9., 1 (1976). 